\title{
4. TRENDS IN NEW SOUTH WALES
}

\section{Confinements and births by plurality}

There were 86,414 births to 85,032 women reported in 2003 (Table 1). Over the last five years the number of births has ranged from about 86,000 to 88,000 . Between 1999 and 2003, the number of twin pregnancies remained fairly stable while the number of triplet pregnancies has declined by about one quarter.

\section{TABLE 1}

BIRTHS AND CONFINEMENTS BY PLURALITY, NSW 1999-2003

\begin{tabular}{|c|c|c|c|c|c|c|c|c|c|c|}
\hline \multirow[t]{2}{*}{ Plurality } & \multicolumn{4}{|c|}{1999} & \multicolumn{2}{|c|}{$\begin{array}{l}\text { Year } \\
2001\end{array}$} & \multicolumn{2}{|c|}{2002} & \multicolumn{2}{|c|}{2003} \\
\hline & No. & $\%$ & No. & $\%$ & No. & $\%$ & No. & $\%$ & No. & $\%$ \\
\hline \multicolumn{11}{|l|}{ Confinements } \\
\hline Singleton & 84676 & 98.5 & 85027 & 98.3 & 82926 & 98.3 & 83190 & 98.3 & 83677 & 98.4 \\
\hline Twins & 1261 & 1.5 & 1404 & 1.6 & 1428 & 1.7 & 1375 & 1.6 & 1330 & 1.6 \\
\hline Triplets & 30 & 0.0 & 29 & 0.0 & 24 & 0.0 & 22 & 0.0 & 23 & 0.0 \\
\hline Quadruplets & 0 & 0.0 & 0 & 0.0 & 1 & 0.0 & 0 & 0.0 & 2 & 0.0 \\
\hline Total & 85967 & 100.0 & 86460 & 100.0 & 84379 & 100.0 & 84587 & 100.0 & 85032 & 100.0 \\
\hline \multicolumn{11}{|l|}{ Births } \\
\hline Singleton & 84676 & 97.0 & 85027 & 96.7 & 82926 & 96.6 & 83190 & 96.7 & 83677 & 96.8 \\
\hline Twins & 2523 & 2.9 & 2808 & 3.2 & 2856 & 3.3 & 2749 & 3.2 & 2660 & 3.1 \\
\hline Triplets & 90 & 0.1 & 87 & 0.1 & 72 & 0.1 & 66 & 0.1 & 69 & 0.1 \\
\hline Quadruplets & 0 & 0.0 & 0 & 0.0 & 4 & 0.0 & 0 & 0.0 & 8 & 0.0 \\
\hline Total & 87289 & 100.0 & 87922 & 100.0 & 85858 & 100.0 & 86005 & 100.0 & 86414 & 100.0 \\
\hline
\end{tabular}

Source: NSW Midwives Data Collection (HOIST). Centre for Epidemiology and Research, NSW Department of Health.

\section{Health area of residence}

In 2003, the largest number of births occurred in the Sydney South West Area, followed by Sydney West and South Eastern Sydney \& Illawarra Areas (Table 2). Over the period 1999 to 2003, there has been a slight decrease in the numbers of births reported in the Hunter \& New England, North Coast, and Greater Southern Areas. There has been little change in the number of births reported annually for other health areas.

\section{TABLE 2}

CONFINEMENTS BY HEALTH AREA OF RESIDENCE, NSW 1999-2003

\begin{tabular}{|c|c|c|c|c|c|c|c|c|c|c|}
\hline \multirow[t]{2}{*}{ Health Area } & \multicolumn{2}{|c|}{1999} & \multicolumn{2}{|c|}{2000} & \multicolumn{2}{|c|}{$\begin{array}{l}\text { Year } \\
2001\end{array}$} & \multicolumn{2}{|c|}{2002} & \multicolumn{2}{|c|}{2003} \\
\hline & No. & $\%$ & No. & $\%$ & No. & $\%$ & No. & $\%$ & No. & $\%$ \\
\hline $\begin{array}{l}\text { Sydney South West } \\
\text { Northern Sydney \& }\end{array}$ & 18844 & 21.9 & 19316 & 22.3 & 18775 & 22.3 & 19105 & 22.6 & 19485 & 22.9 \\
\hline Central Coast & 12907 & 15.0 & 13204 & 15.3 & 12856 & 15.2 & 12818 & 15.2 & 13142 & 15.5 \\
\hline Sydney West & 15822 & 18.4 & 15967 & 18.5 & 15763 & 18.7 & 15883 & 18.8 & 15942 & 18.7 \\
\hline $\begin{array}{l}\text { Hunter \& New England } \\
\text { South Eastern Sydney \& }\end{array}$ & 10168 & 11.8 & 10105 & 11.7 & 9753 & 11.6 & 10004 & 11.8 & 9694 & 11.4 \\
\hline Illawarra & 13841 & 16.1 & 14104 & 16.3 & 13589 & 16.1 & 13699 & 16.2 & 13898 & 16.3 \\
\hline North Coast & 4954 & 5.8 & 4709 & 5.4 & 4762 & 5.6 & 4656 & 5.5 & 4587 & 5.4 \\
\hline Greater Western & 4167 & 4.8 & 4135 & 4.8 & 4110 & 4.9 & 3855 & 4.6 & 3898 & 4.6 \\
\hline Greater Southern & 4448 & 5.2 & 4283 & 5.0 & 4209 & 5.0 & 3969 & 4.7 & 3834 & 4.5 \\
\hline Other/Not stated & 816 & 0.9 & 637 & 0.7 & 562 & 0.7 & 598 & 0.7 & 552 & 0.6 \\
\hline TOTAL & 85967 & 100.0 & 86460 & 100.0 & 84379 & 100.0 & 84587 & 100.0 & 85032 & 100.0 \\
\hline
\end{tabular}

Source: NSW Midwives Data Collection (HOIST). Centre for Epidemiology and Research, NSW Department of Health. 


\section{Maternal age}

The number of teenage mothers decreased from 4,099 in 1999 to 3,386 in 2003 , a fall from 4.8 to 4.0 per cent of all confinements; while the number of mothers 35 years of age or over increased from 14,668 in 1999 to 16,447 in 2003, an increase from 17.1 to 19.3 per cent of all confinements (Figure 1, Table 3). The mean maternal age rose from 29.6 to 30.2 years over the 5-year period.
The trend towards later childbirth is evident among both primiparous and multiparous mothers: the proportion of mothers giving birth for the first time who were aged 35 years or more increased from 10.4 to 12.3 per cent over the 5-year period, and the proportion of multiparous mothers who were aged 35 years or more increased from 21.7 to 24.5 per cent. The mean maternal age rose from 27.9 to 28.5 years for primiparous mothers and from 30.8 to 31.4 years for multiparous mothers.

\section{FIGURE 1}

CONFINEMENTS AMONG MOTHERS AGED LESS THAN 20 YEARS AND 35 YEARS AND OVER, NSW 1999-2003

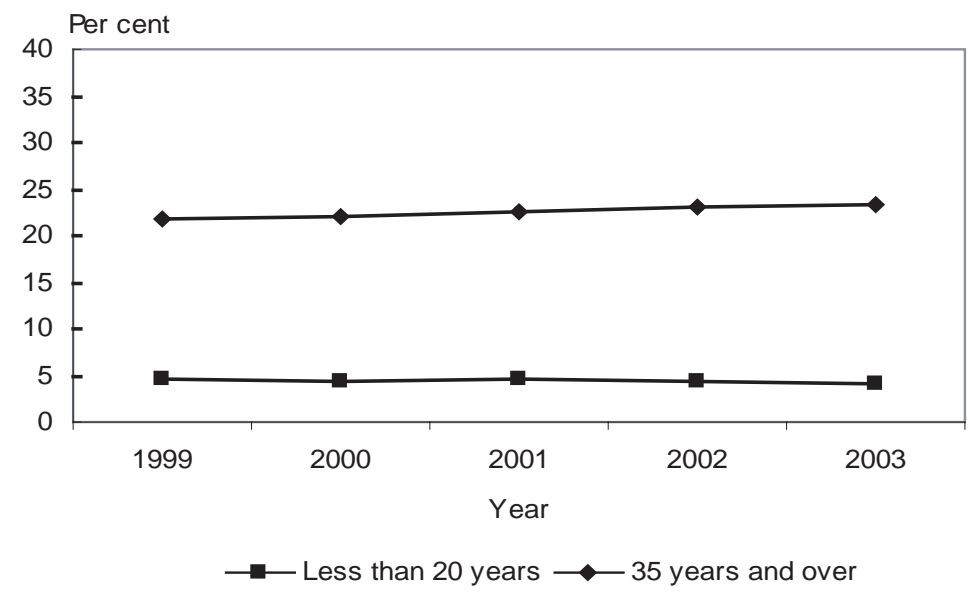

Source: NSW Midwives Data Collection (HOIST). Centre for Epidemiology and Research, NSW Department of Health.

\section{TABLE 3}

CONFINEMENTS BY MATERNAL AGE, NSW 1999-2003

\begin{tabular}{|c|c|c|c|c|c|c|c|c|c|c|}
\hline \multirow[t]{2}{*}{$\begin{array}{l}\text { Maternal age } \\
\text { (years) }\end{array}$} & \multicolumn{2}{|c|}{1999} & \multicolumn{4}{|c|}{$\begin{array}{l}\text { Year } \\
2001\end{array}$} & \multicolumn{2}{|c|}{2002} & \multicolumn{2}{|c|}{2003} \\
\hline & No. & $\%$ & No. & $\%$ & No. & $\%$ & No. & $\%$ & No. & $\%$ \\
\hline Under 15 & 27 & 0.0 & 31 & 0.0 & 19 & 0.0 & 28 & 0.0 & 23 & 0.0 \\
\hline $15-19$ & 4072 & 4.7 & 3822 & 4.4 & 3778 & 4.5 & 3624 & 4.3 & 3363 & 4.0 \\
\hline $20-24$ & 13790 & 16.0 & 13316 & 15.4 & 13036 & 15.4 & 12674 & 15.0 & 12529 & 14.7 \\
\hline $25-29$ & 27678 & 32.2 & 27293 & 31.6 & 25528 & 30.3 & 24523 & 29.0 & 24138 & 28.4 \\
\hline $30-34$ & 25703 & 29.9 & 26640 & 30.8 & 26707 & 31.7 & 27810 & 32.9 & 28522 & 33.5 \\
\hline $35-39$ & 12372 & 14.4 & 12894 & 14.9 & 12640 & 15.0 & 13107 & 15.5 & 13582 & 16.0 \\
\hline $40-44$ & 2199 & 2.6 & 2342 & 2.7 & 2488 & 2.9 & 2645 & 3.1 & 2752 & 3.2 \\
\hline $45+$ & 97 & 0.1 & 98 & 0.1 & 122 & 0.1 & 120 & 0.1 & 113 & 0.1 \\
\hline Not stated & 29 & 0.0 & 24 & 0.0 & 61 & 0.1 & 56 & 0.1 & 10 & 0.0 \\
\hline TOTAL & 85967 & 100.0 & 86460 & 100.0 & 84379 & 100.0 & 84587 & 100.0 & 85032 & 100.0 \\
\hline
\end{tabular}

Source: NSW Midwives Data Collection (HOIST). Centre for Epidemiology and Research, NSW Department of Health. 


\section{Maternal country of birth}

In the period 1999-2003, about 73 per cent of confinements were to mothers who were born in Australia. In 2003, mothers born in the United Kingdom, New Zealand, Vietnam, Lebanon and China together accounted for 11.3 per cent of all confinements (Table 4). Further information on maternal country of birth is shown in Chapter 7.

\section{TABLE 4}

CONFINEMENTS BY MATERNAL COUNTRY OF BIRTH, NSW 1999-2003\#

\begin{tabular}{|c|c|c|c|c|c|c|c|c|c|c|}
\hline \multirow[t]{2}{*}{ Country of birth } & \multicolumn{4}{|c|}{1999} & \multicolumn{2}{|c|}{$\begin{array}{l}\text { Year } \\
2001\end{array}$} & \multicolumn{2}{|c|}{2002} & \multicolumn{2}{|c|}{2003} \\
\hline & No. & $\%$ & No. & $\%$ & No. & $\%$ & No. & $\%$ & No. & $\%$ \\
\hline Australia & 62555 & 72.8 & 62368 & 72.1 & 61655 & 73.1 & 61631 & 72.9 & 61430 & 72.2 \\
\hline United Kingdom & 2627 & 3.1 & 2557 & 3.0 & 2331 & 2.8 & 2344 & 2.8 & 2368 & 2.8 \\
\hline New Zealand & 1966 & 2.3 & 1962 & 2.3 & 2009 & 2.4 & 1998 & 2.4 & 2121 & 2.5 \\
\hline Vietnam & 1804 & 2.1 & 2053 & 2.4 & 1691 & 2.0 & 1773 & 2.1 & 1863 & 2.2 \\
\hline Lebanon & 1788 & 2.1 & 1766 & 2.0 & 1667 & 2.0 & 1663 & 2.0 & 1696 & 2.0 \\
\hline China & 2015 & 2.3 & 2163 & 2.5 & 1791 & 2.1 & 1830 & 2.2 & 1586 & 1.9 \\
\hline Philippines & 1319 & 1.5 & 1315 & 1.5 & 1243 & 1.5 & 1156 & 1.4 & 1192 & 1.4 \\
\hline India & 635 & 0.7 & 643 & 0.7 & 612 & 0.7 & 747 & 0.9 & 810 & 1.0 \\
\hline Fiji & 604 & 0.7 & 688 & 0.8 & 652 & 0.8 & 655 & 0.8 & 691 & 0.8 \\
\hline Iraq & 414 & 0.5 & 455 & 0.5 & 577 & 0.7 & 545 & 0.6 & 648 & 0.8 \\
\hline Former Yugoslavia & 662 & 0.8 & 627 & 0.7 & 607 & 0.7 & 531 & 0.6 & 571 & 0.7 \\
\hline Indonesia & 460 & 0.5 & 566 & 0.7 & 494 & 0.6 & 494 & 0.6 & 489 & 0.6 \\
\hline South Africa & 386 & 0.4 & 387 & 0.4 & 450 & 0.5 & 486 & 0.6 & 486 & 0.6 \\
\hline United States of America & 372 & 0.4 & 377 & 0.4 & 332 & 0.4 & 346 & 0.4 & 355 & 0.4 \\
\hline Ireland & 287 & 0.3 & 273 & 0.3 & 291 & 0.3 & 267 & 0.3 & 333 & 0.4 \\
\hline South Korea & 370 & 0.4 & 426 & 0.5 & 358 & 0.4 & 301 & 0.4 & 328 & 0.4 \\
\hline Western Samoa & 318 & 0.4 & 320 & 0.4 & 319 & 0.4 & 310 & 0.4 & 303 & 0.4 \\
\hline Hong Kong & 409 & 0.5 & 357 & 0.4 & 332 & 0.4 & 307 & 0.4 & 301 & 0.4 \\
\hline Sri Lanka & 295 & 0.3 & 304 & 0.4 & 291 & 0.3 & 324 & 0.4 & 299 & 0.4 \\
\hline Cambodia & 303 & 0.4 & 326 & 0.4 & 285 & 0.3 & 279 & 0.3 & 295 & 0.3 \\
\hline Japan & 264 & 0.3 & 252 & 0.3 & 293 & 0.3 & 283 & 0.3 & 293 & 0.3 \\
\hline Malaysia & 286 & 0.3 & 319 & 0.4 & 251 & 0.3 & 262 & 0.3 & 271 & 0.3 \\
\hline Turkey & 314 & 0.4 & 335 & 0.4 & 317 & 0.4 & 266 & 0.3 & 265 & 0.3 \\
\hline Pakistan & 192 & 0.2 & 224 & 0.3 & 276 & 0.3 & 266 & 0.3 & 260 & 0.3 \\
\hline Thailand & 207 & 0.2 & 199 & 0.2 & 221 & 0.3 & 268 & 0.3 & 253 & 0.3 \\
\hline Germany & 226 & 0.3 & 204 & 0.2 & 192 & 0.2 & 188 & 0.2 & 237 & 0.3 \\
\hline Canada & 185 & 0.2 & 177 & 0.2 & 203 & 0.2 & 192 & 0.2 & 225 & 0.3 \\
\hline Tonga & 308 & 0.4 & 296 & 0.3 & 278 & 0.3 & 271 & 0.3 & 219 & 0.3 \\
\hline North Korea & 90 & 0.1 & 140 & 0.2 & 102 & 0.1 & 151 & 0.2 & 206 & 0.2 \\
\hline Bangladesh & 134 & 0.2 & 179 & 0.2 & 183 & 0.2 & 212 & 0.3 & 198 & 0.2 \\
\hline Iran & 140 & 0.2 & 153 & 0.2 & 169 & 0.2 & 137 & 0.2 & 192 & 0.2 \\
\hline Chile & 224 & 0.3 & 202 & 0.2 & 206 & 0.2 & 250 & 0.3 & 187 & 0.2 \\
\hline Egypt & 218 & 0.3 & 196 & 0.2 & 176 & 0.2 & 160 & 0.2 & 173 & 0.2 \\
\hline Syria & 145 & 0.2 & 138 & 0.2 & 150 & 0.2 & 151 & 0.2 & 154 & 0.2 \\
\hline Papua New Guinea & 136 & 0.2 & 132 & 0.2 & 133 & 0.2 & 135 & 0.2 & 148 & 0.2 \\
\hline Afghanistan & 120 & 0.1 & 96 & 0.1 & 147 & 0.2 & 133 & 0.2 & 143 & 0.2 \\
\hline Singapore & 101 & 0.1 & 104 & 0.1 & 119 & 0.1 & 117 & 0.1 & 129 & 0.2 \\
\hline Sudan & 51 & 0.1 & 57 & 0.1 & 65 & 0.1 & 69 & 0.1 & 117 & 0.1 \\
\hline Poland & 123 & 0.1 & 104 & 0.1 & 92 & 0.1 & 106 & 0.1 & 116 & 0.1 \\
\hline Laos & 118 & 0.1 & 136 & 0.2 & 118 & 0.1 & 128 & 0.2 & 114 & 0.1 \\
\hline Italy & 221 & 0.3 & 191 & 0.2 & 139 & 0.2 & 70 & 0.1 & 106 & 0.1 \\
\hline Russian Federation & 33 & 0.0 & 56 & 0.1 & 63 & 0.1 & 105 & 0.1 & 106 & 0.1 \\
\hline Argentina & 87 & 0.1 & 89 & 0.1 & 89 & 0.1 & 81 & 0.1 & 106 & 0.1 \\
\hline Other/Not stated & 2455 & 2.9 & 2548 & 2.9 & 2410 & 2.9 & 2599 & 3.1 & 2649 & 3.1 \\
\hline TOTAL & 85967 & 100.0 & 86460 & 100.0 & 84379 & 100.0 & 84587 & 100.0 & 85032 & 100.0 \\
\hline
\end{tabular}

Source: NSW Midwives Data Collection (HOIST). Centre for Epidemiology and Research, NSW Department of Health.

\# $\quad$ Countries of birth for which there were 100 or more confinements in 2003. 


\section{Maternal Aboriginality}

The reported number of Aboriginal or Torres Strait Islander mothers giving birth increased marginally from 2,059 in 1999 (2.4 per cent of all mothers) to 2,161 in
2003 (2.5 per cent of all mothers) (Table 5). Further information on maternal Aboriginality and reporting of Aborginality is shown in Chapter 6.

\section{TABLE 5}

CONFINEMENTS BY MATERNAL ABORIGINALITY, NSW 1999-2003

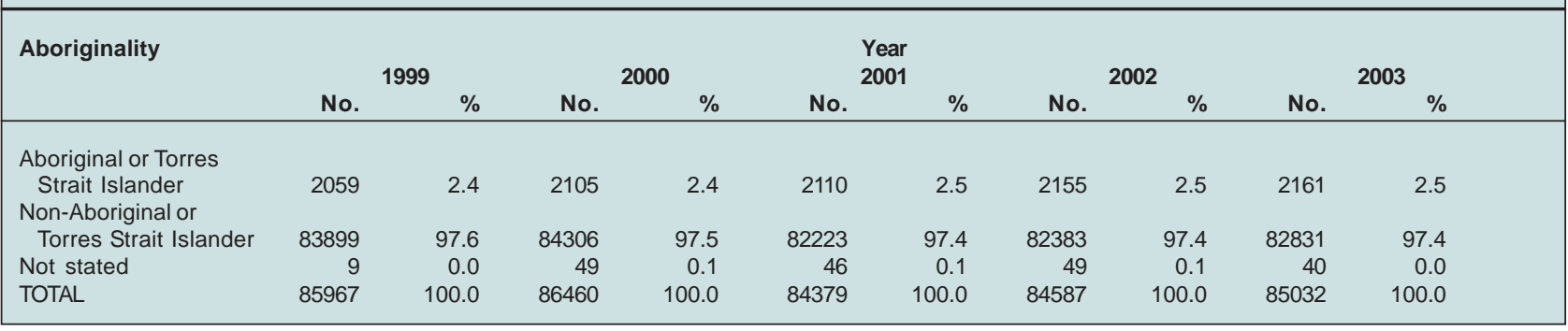

Source: NSW Midwives Data Collection (HOIST). Centre for Epidemiology and Research, NSW Department of Health.

\section{Number of previous pregnancies}

In recent years there were no substantial changes in the reported number of previous pregnancies greater than 20 weeks gestation (Table 6). The proportion of mothers giving birth for the first time has been stable at 41 to 42 per cent, while the proportion of mothers giving birth to a second to fifth baby has been stable at about 57 per cent. Less than 2 per cent of mothers have previously given birth 5 times or more.

\section{TABLE 6}

CONFINEMENTS BY NUMBER OF PREVIOUS PREGNANCIES, NSW 1999-2003

Number of previous

pregnancies

( $>20$ weeks gestation)

$1-4$

$5+$

Not stated

TOTAL

\begin{tabular}{rrrr} 
& \multicolumn{3}{c}{$\mathbf{2} 2000$} \\
No. & $\%$ & No. \\
35311 & 41.1 & 35953 & 41 \\
49432 & 57.5 & 49146 & 56 \\
1206 & 1.4 & 1331 & 1.8 \\
18 & 0.0 & 30 & 0 \\
85967 & 100.0 & 86460 & 100
\end{tabular}

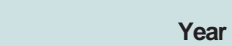

$\% \quad$ No.

$2001 \%$

35153

$56.8 \quad 47850$

$1.5 \quad 1329$

47

84379

$\% \quad$ No.

\begin{tabular}{rr}
2002 \\
No. & \\
\hline 035 & 41 \\
169 & 56 \\
290 & 1 \\
93 & 0 \\
587 & 100 \\
\hline
\end{tabular}

\begin{tabular}{rrr}
$\%$ & No. & \% \\
\hline 1.4 & 35879 & 42.2 \\
6.9 & 47847 & 56.3 \\
1.5 & 1258 & 1.5 \\
0.1 & 48 & 0.1 \\
.0 & 85032 & 100.0
\end{tabular}

Source: NSW Midwives Data Collection (HOIST). Centre for Epidemiology and Research, NSW Department of Health.

\section{Duration of pregnancy at first antenatal visit}

Since 1999, the proportion of mothers starting antenatal care at 20-plus weeks gestation has been stable at 12-13 per cent (Table 7).

\section{TABLE 7}

CONFINEMENTS BY DURATION OF PREGNANCY AT FIRST ANTENATAL VISIT, NSW 1999-2003

\begin{tabular}{|c|c|c|c|c|c|c|c|c|c|c|}
\hline \multirow[t]{2}{*}{$\begin{array}{l}\text { Duration of } \\
\text { pregnancy (weeks) }\end{array}$} & \multicolumn{2}{|c|}{1999} & \multicolumn{2}{|c|}{2000} & \multicolumn{2}{|c|}{$\begin{array}{l}\text { Year } \\
2001\end{array}$} & \multicolumn{2}{|c|}{2002} & \multicolumn{2}{|c|}{2003} \\
\hline & No. & $\%$ & No. & $\%$ & No. & $\%$ & No. & $\%$ & No. & $\%$ \\
\hline 0-19 & 74077 & 86.2 & 74803 & 86.5 & 72704 & 86.2 & 73116 & 86.4 & 73615 & 86.6 \\
\hline 20-plus & 10979 & 12.8 & 10748 & 12.4 & 10878 & 12.9 & 10614 & 12.5 & 10929 & 12.9 \\
\hline Not stated & 911 & 1.1 & 909 & 1.1 & 797 & 0.9 & 857 & 1.0 & 488 & 0.6 \\
\hline TOTAL & 85967 & 100.0 & 86460 & 100.0 & 84379 & 100.0 & 84587 & 100.0 & 85032 & 100.0 \\
\hline
\end{tabular}

Source: NSW Midwives Data Collection (HOIST). Centre for Epidemiology and Research, NSW Department of Health. 


\section{Smoking in pregnancy}

The proportion of mothers reporting any smoking during pregnancy declined between 1999 and 2003: in 1999, 16,302 (19.0 per cent) mothers reported smoking in pregnancy, compared to 15,001 (17.4 per cent) in 2000, 14,424 (17.1 per cent) in $2001,13,829$ (16.3 per cent) in 2002 and 12,875 (15.1 per cent) in 2003 .
Of mothers who smoked during pregnancy in 2003, 3.3 per cent stopped smoking before the second half of pregnancy. Over the five year period, among those who smoked in the second half of pregnancy, there was a trend towards smoking fewer cigarettes per day (Table 8).

\section{TABLE 8}

MOTHERS WHO SMOKED AT ALL DURING PREGNANCY BY NUMBER OF CIGARETTES SMOKED IN THE SECOND HALF OF PREGNANCY, NSW 1999-2003

\begin{tabular}{|c|c|c|c|c|c|c|c|c|c|c|}
\hline \multirow[t]{2}{*}{$\begin{array}{l}\text { Cigarettes smoked in the } \\
\text { second half of pregnancy }\end{array}$} & \multicolumn{2}{|c|}{1999} & \multicolumn{3}{|c|}{2000} & $\begin{array}{l}\text { Year } \\
2001\end{array}$ & \multicolumn{2}{|c|}{2002} & \multicolumn{2}{|c|}{2003} \\
\hline & No. & $\%$ & No. & $\%$ & No. & $\%$ & No. & $\%$ & No. & $\%$ \\
\hline None & 739 & 4.5 & 622 & 4.1 & 576 & 4.0 & 556 & 4.0 & 427 & 3.3 \\
\hline $1-10$ per day & 7303 & 44.8 & 7092 & 47.3 & 6834 & 47.4 & 6639 & 48.0 & 6451 & 50.1 \\
\hline More than ten per day & 7966 & 48.9 & 7005 & 46.7 & 6725 & 46.6 & 6347 & 45.9 & 5680 & 44.1 \\
\hline Smoked, amount not stated & 294 & 1.8 & 282 & 1.9 & 289 & 2.0 & 279 & 2.0 & 317 & 2.5 \\
\hline Not stated & 0 & 0.0 & 0 & 0.0 & 0 & 0.0 & 8 & 0.1 & 0 & 0.0 \\
\hline TOTAL & 16302 & 100.0 & 15001 & 100.0 & 14424 & 100.0 & 13829 & 100.0 & 12875 & 100.0 \\
\hline
\end{tabular}

Source: NSW Midwives Data Collection (HOIST). Centre for Epidemiology and Research, NSW Department of Health.

\section{Place of birth}

In 2003, the majority of mothers planned to give birth in a hospital labour ward, and 3.7 per cent of mothers planned to give birth in a birth centre (Table 9). About two-thirds of mothers who planned to give birth in a birth centre actually did so. The number of reported planned homebirths declined from 182 in 1999 to 132 in 2003.

\section{TABLE 9}

CONFINEMENTS BY PLACE OF BIRTH, NSW 1999-2003

\begin{tabular}{|c|c|c|c|c|c|c|c|c|c|c|}
\hline \multirow[t]{3}{*}{ Place of birth } & \multicolumn{10}{|c|}{ Year } \\
\hline & \multicolumn{2}{|c|}{1999} & \multicolumn{2}{|c|}{2000} & \multicolumn{2}{|c|}{2001} & \multicolumn{2}{|c|}{2002} & \multicolumn{2}{|c|}{2003} \\
\hline & No. & $\%$ & No. & $\%$ & No. & $\%$ & No. & $\%$ & No. & $\%$ \\
\hline Hospital & 82103 & 95.5 & 82782 & 95.7 & 80984 & 96.0 & 81230 & 96.0 & 81441 & 95.8 \\
\hline Birth centre & 2249 & 2.6 & 2205 & 2.6 & 2038 & 2.4 & 2030 & 2.4 & 2075 & 2.4 \\
\hline $\begin{array}{c}\text { Planned birth centre/ } \\
\text { hospital admission }\end{array}$ & 1070 & 1.2 & 959 & 1.1 & 822 & 1.0 & 881 & 1.0 & 1029 & 1.2 \\
\hline Planned homebirth & 139 & 0.2 & 108 & 0.1 & 144 & 0.2 & 99 & 0.1 & 109 & 0.1 \\
\hline $\begin{array}{l}\text { Planned homebirth/ } \\
\text { hospital admission }\end{array}$ & 43 & 0.1 & 38 & 0.0 & 38 & 0.0 & 31 & 0.0 & 23 & 0.0 \\
\hline Born before arrival & 363 & 0.4 & 366 & 0.4 & 353 & 0.4 & 316 & 0.4 & 355 & 0.4 \\
\hline Not stated & 0 & 0.0 & 2 & 0.0 & 0 & 0.0 & 0 & 0.0 & 0 & 0.0 \\
\hline TOTAL & 85967 & 100.0 & 86460 & 100.0 & 84379 & 100.0 & 84587 & 100.0 & 85032 & 100.0 \\
\hline
\end{tabular}

Source: NSW Midwives Data Collection (HOIST). Centre for Epidemiology and Research, NSW Department of Health. 


\section{Hypertension and diabetes}

In 2003, pre-eclampsia was reported in 5.5 per cent of mothers, a slight fall from 7.2 per cent in 1999. Essential hypertension was reported in about 1 per cent of mothers, a rate that has not changed substantially over the last five years (Table 10).
In 2003, gestational diabetes was reported in 4.5 per cent of mothers, rising from 3.8 per cent reported in 1999, while rates of diabetes mellitus have remained stable at about 0.5 per cent over the five-year period.

\section{TABLE 10}

CONFINEMENTS BY PRESENCE OF HYPERTENSION OR DIABETES, NSW 1999-2003

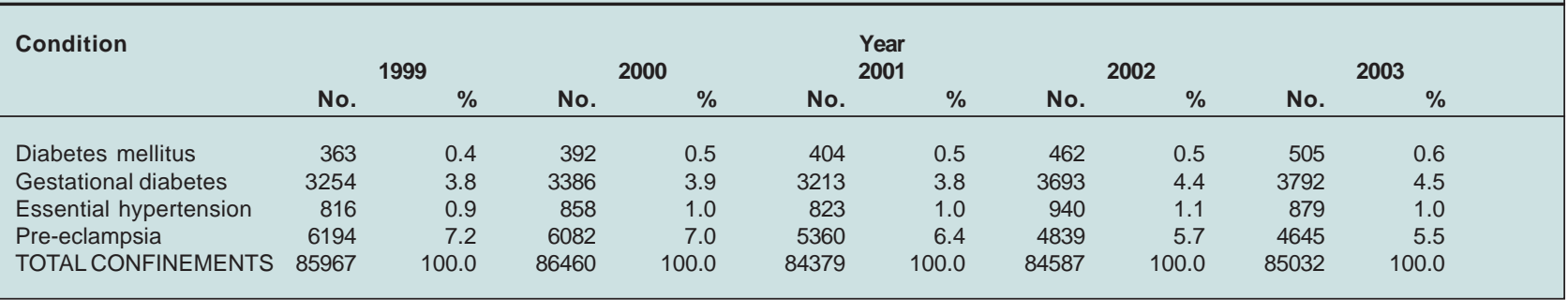

Source: NSW Midwives Data Collection (HOIST). Centre for Epidemiology and Research, NSW Department of Health.

\section{Labour}

The rate of spontaneous onset of labour fell from 65.4 per cent in 1999 to 60.4 per cent in 2003 (Table 11). Nine per cent of labours were augmented with oxytocics or prostaglandins in 2003. The rate of induction of labour was 24.5 per cent in 2003 , similar to previous years. The most common reported reason for induction of labour in 2003 was prolonged pregnancy (41 or more weeks) (34.7 per cent), followed by hypertensive disease (11.1 per cent), prelabour rupture of membranes (10.7 per cent), suspected intrauterine growth retardation (4.0 per cent), diabetes (3.9 per cent) and fetal death $(0.9$ per cent $)$.

\section{TABLE 11}

\section{CONFINEMENTS BY ONSET AND AUGMENTATION OF LABOUR, NSW 1999-2003}

\begin{tabular}{|c|c|c|c|c|c|c|c|c|c|c|}
\hline \multirow[t]{3}{*}{ Onset of labour } & \multirow{2}{*}{\multicolumn{4}{|c|}{1999}} & \multirow{2}{*}{\multicolumn{2}{|c|}{$\begin{array}{l}\text { Year } \\
2001\end{array}$}} & \multirow{2}{*}{\multicolumn{2}{|c|}{2002}} & \multirow{2}{*}{\multicolumn{2}{|c|}{2003}} \\
\hline & & & & & & & & & & \\
\hline & No. & $\%$ & No. & $\%$ & No. & $\%$ & No. & $\%$ & No. & $\%$ \\
\hline Spontaneous & 39706 & 46.2 & 40042 & 46.3 & 37492 & 44.4 & 37615 & 44.5 & 38110 & 44.8 \\
\hline Spontaneous & & & & & & & & & & \\
\hline augmented with ARM & 7844 & 9.1 & 7014 & 8.1 & 6684 & 7.9 & 6422 & 7.6 & 5992 & 7.0 \\
\hline $\begin{array}{l}\text { Spontaneous } \\
\text { augmented with } \\
\text { oxytocics- }\end{array}$ & & & & & & & & & & \\
\hline prostaglandins & 8657 & 10.1 & 9050 & 10.5 & 8297 & 9.8 & 7644 & 9.0 & 7258 & 8.5 \\
\hline No labour & 9147 & 10.6 & 9926 & 11.5 & 10986 & 13.0 & 11720 & 13.9 & 12820 & 15.1 \\
\hline $\begin{array}{l}\text { Induced- } \\
\text { oxytocics- }\end{array}$ & & & & & & & & & & \\
\hline prostaglandins & 7626 & 8.9 & 7493 & 8.7 & 7422 & 8.8 & 7414 & 8.8 & 7265 & 8.5 \\
\hline Induced-ARM only & 1305 & 1.5 & 1196 & 1.4 & 1181 & 1.4 & 1193 & 1.4 & 1331 & 1.6 \\
\hline $\begin{array}{l}\text { Induced- } \\
\text { ARM+oxytocics- } \\
\text { prostaglandins }\end{array}$ & 11527 & 13.4 & 11516 & 13.3 & 12033 & 14.3 & 12262 & 14.5 & 11965 & 14.1 \\
\hline Induced-other\# & 154 & 0.2 & 215 & 0.2 & 277 & 0.3 & 305 & 0.4 & 289 & 0.3 \\
\hline Not stated & 1 & 0.0 & 8 & 0.0 & 7 & 0.0 & 12 & 0.0 & 2 & 0.0 \\
\hline TOTAL & 85967 & 100.0 & 86460 & 100.0 & 84379 & 100.0 & 84587 & 100.0 & 85032 & 100.0 \\
\hline
\end{tabular}

Source: NSW Midwives Data Collection (HOIST). Centre for Epidemiology and Research, NSW Department of Health.

\# This category includes other forms of induction such at Foley's catheter. 


\section{Delivery}

The rate of normal vaginal birth decreased from 68.6 per cent in 1999 to 62.8 per cent in 2003 (Table 12). The caesarean section rate increased from 19.7 to 26.5 per cent. The rate of instrumental delivery remained steady at 10 to 11 per cent, accompanied by a change in the pattern of instrumental delivery: the rate of vacuum extraction rose from 6.0 to 6.8 per cent and the rate of forceps delivery declined from 4.9 to 3.4 per cent.
Operative and instrumental deliveries are more common among privately than publicly insured mothers (Table 13). Among privately insured mothers the rate of normal vaginal birth fell from 58.7 to 52.4 per cent and the caesarean section rate increased from 24.9 to 32.2 per cent. Among publicly insured mothers the rate of normal vaginal birth fell from 73.8 to 70.4 per cent and the caesarean section rate rose from 16.8 to 20.9 per cent.

\section{TABLE 12}

\section{CONFINEMENTS BY TYPE OF DELIVERY, NSW 1999-2003}

\begin{tabular}{|c|c|c|c|c|c|c|c|c|c|c|}
\hline \multirow[t]{2}{*}{ Type of delivery } & \multicolumn{4}{|c|}{1999} & \multicolumn{2}{|c|}{$\begin{array}{l}\text { Year } \\
2001\end{array}$} & \multicolumn{2}{|c|}{2002} & \multicolumn{2}{|c|}{2003} \\
\hline & No. & $\%$ & No. & $\%$ & No. & $\%$ & No. & $\%$ & No. & $\%$ \\
\hline Normal vaginal & 58951 & 68.6 & 58049 & 67.1 & 55206 & 65.4 & 54271 & 64.2 & 53424 & 62.8 \\
\hline Forceps & 4190 & 4.9 & 3904 & 4.5 & 3398 & 4.0 & 3034 & 3.6 & 2875 & 3.4 \\
\hline Vacuum extraction & 5152 & 6.0 & 5367 & 6.2 & 5499 & 6.5 & 5855 & 6.9 & 5788 & 6.8 \\
\hline $\begin{array}{l}\text { Vaginal breech } \\
\text { Elective caesarean }\end{array}$ & 762 & 0.9 & 669 & 0.8 & 383 & 0.5 & 353 & 0.4 & 371 & 0.4 \\
\hline $\begin{array}{l}\text { section } \\
\text { Emergency caesarean }\end{array}$ & 9147 & 10.6 & 9926 & 11.5 & 10986 & 13.0 & 11720 & 13.9 & 12820 & 15.1 \\
\hline section\# & 7765 & 9.0 & 8530 & 9.9 & 8894 & 10.5 & 9335 & 11.0 & 9744 & 11.5 \\
\hline Not stated & 0 & 0.0 & 15 & 0.0 & 13 & 0.0 & 19 & 0.0 & 10 & 0.0 \\
\hline TOTAL & 85967 & 100.0 & 86460 & 100.0 & 84379 & 100.0 & 84587 & 100.0 & 85032 & 100.0 \\
\hline
\end{tabular}

Source: NSW Midwives Data Collection (HOIST). Centre for Epidemiology and Research, NSW Department of Health.

\# Emergency caesarean section includes caesarean sections where the onset of labour was not stated.

\section{TABLE 13}

\section{CONFINEMENTS BY HEALTH INSURANCE STATUS AND TYPE OF DELIVERY, NSW 1998-2002}

\begin{tabular}{|c|c|c|c|c|c|c|c|c|c|c|}
\hline \multirow{3}{*}{$\begin{array}{l}\text { Insurance status- } \\
\text { type of delivery }\end{array}$} & \multirow{2}{*}{\multicolumn{8}{|c|}{ Year }} & \multirow{2}{*}{\multicolumn{2}{|c|}{2002}} \\
\hline & & & & & & & & & & \\
\hline & No. & $\%$ & No. & $\%$ & No. & $\%$ & No. & $\%$ & No. & $\%$ \\
\hline \multicolumn{11}{|l|}{ Public } \\
\hline Normal vaginal & 43988 & 73.8 & 44683 & 72.8 & 43462 & 71.8 & 39541 & 71.3 & 38228 & 70.4 \\
\hline Forceps & 2358 & 4.0 & 2437 & 4.0 & 2191 & 3.6 & 1673 & 3.0 & 1430 & 2.6 \\
\hline Vacuum extraction & 2644 & 4.4 & 3173 & 5.2 & 3100 & 5.1 & 2868 & 5.2 & 2995 & 5.5 \\
\hline Vaginal breech & 615 & 1.0 & 601 & 1.0 & 505 & 0.8 & 286 & 0.5 & 253 & 0.5 \\
\hline Elective caesarean section & 5030 & 8.4 & 5242 & 8.5 & 5594 & 9.2 & 5658 & 10.2 & 5854 & 10.8 \\
\hline Emergency caesarean section\# & 4987 & 8.4 & 5263 & 8.6 & 5627 & 9.3 & 5438 & 9.8 & 5512 & 10.2 \\
\hline Not stated & 13 & 0.0 & 0 & 0.0 & 12 & 0.0 & 3 & 0.0 & 7 & 0.0 \\
\hline TOTAL & 59635 & 100.0 & 61399 & 100.0 & 60491 & 100.0 & 55467 & 100.0 & 54279 & 100.0 \\
\hline \multicolumn{11}{|l|}{ Private } \\
\hline Normal vaginal & 14304 & 58.7 & 13674 & 57.6 & 13652 & 55.5 & 14715 & 53.6 & 15261 & 52.4 \\
\hline Forceps & 2077 & 8.5 & 1728 & 7.3 & 1669 & 6.8 & 1684 & 6.1 & 1578 & 5.4 \\
\hline Vacuum extraction & 1767 & 7.2 & 1953 & 8.2 & 2199 & 8.9 & 2558 & 9.3 & 2801 & 9.6 \\
\hline Vaginal breech & 158 & 0.6 & 134 & 0.6 & 135 & 0.5 & 76 & 0.3 & 82 & 0.3 \\
\hline Elective caesarean section & 3695 & 15.2 & 3810 & 16.0 & 4159 & 16.9 & 5114 & 18.6 & 5689 & 19.5 \\
\hline Emergency caesarean section\# & 2365 & 9.7 & 2443 & 10.3 & 2762 & 11.2 & 3300 & 12.0 & 3683 & 12.7 \\
\hline Not stated & 10 & 0.0 & 0 & 0.0 & 3 & 0.0 & 10 & 0.0 & 12 & 0.0 \\
\hline TOTAL & 24376 & 100.0 & 23742 & 100.0 & 24579 & 100.0 & 27457 & 100.0 & 29106 & 100.0 \\
\hline \multicolumn{11}{|l|}{ TOTAL\#\# } \\
\hline Normal vaginal & 59097 & 69.5 & 58951 & 68.6 & 58049 & 67.1 & 55206 & 65.4 & 54271 & 64.2 \\
\hline Forceps & 4478 & 5.3 & 4190 & 4.9 & 3904 & 4.5 & 3398 & 4.0 & 3034 & 3.6 \\
\hline Vacuum extraction & 4453 & 5.2 & 5152 & 6.0 & 5367 & 6.2 & 5499 & 6.5 & 5855 & 6.9 \\
\hline Vaginal breech & 805 & 0.9 & 762 & 0.9 & 669 & 0.8 & 383 & 0.5 & 353 & 0.4 \\
\hline Elective caesarean section & 8800 & 10.3 & 9147 & 10.6 & 9926 & 11.5 & 10986 & 13.0 & 11720 & 13.9 \\
\hline Emergency caesarean section\# & 7416 & 8.7 & 7765 & 9.0 & 8530 & 9.9 & 8894 & 10.5 & 9335 & 11.0 \\
\hline Not stated & 23 & 0.0 & 0 & 0.0 & 15 & 0.0 & 13 & 0.0 & 19 & 0.0 \\
\hline TOTAL & 85072 & 100.0 & 85967 & 100.0 & 86460 & 100.0 & 84379 & 100.0 & 84587 & 100.0 \\
\hline
\end{tabular}

Source: Linked data of the NSW Midwives Data Collection and NSW Inpatient Statistics Collection. Centre for Epidemiology and Research, NSW Department of Health.

\# Emergency caesarean section includes caesarean sections where the onset of labour was not stated.

\#\# Total includes confinements where type of health insurance was not stated. 


\section{Pain relief}

There has been a trend towards increased use of spinal anaesthetics, from 4.9 per cent in 1999 to 12.6 per cent in 2003. The proportion of mothers having no pain relief during labour or delivery decreased from 13.3 per cent in 1999 to 10.5 per cent in 2003 (Table 14). In 2003, almost one half (46.5 per cent) of all mothers used nitrous oxide for pain relief, 27.7 per cent had an epidural anaesthetic, and 24.8 per cent received intra-muscular narcotics.

\section{TABLE 14}

CONFINEMENTS BY TYPE OF PAIN RELIEF, NSW 1999-2003

\begin{tabular}{|c|c|c|c|c|c|c|c|c|c|c|}
\hline \multirow[t]{3}{*}{ Type of pain relief } & \multicolumn{10}{|c|}{ Year } \\
\hline & \multicolumn{2}{|c|}{1999} & \multicolumn{2}{|c|}{2000} & \multicolumn{2}{|c|}{2001} & \multicolumn{2}{|c|}{2002} & \multicolumn{2}{|c|}{2003} \\
\hline & No. & $\%$ & No. & $\%$ & No. & $\%$ & No. & $\%$ & No. & $\%$ \\
\hline Epidural & 24289 & 28.3 & 25728 & 29.8 & 24572 & 29.1 & 23543 & 27.8 & 23569 & 27.7 \\
\hline General anaesthetic & 4735 & 5.5 & 4753 & 5.5 & 4866 & 5.8 & 4811 & 5.7 & 4636 & 5.5 \\
\hline IM Narcotics & 22800 & 26.5 & 22654 & 26.2 & 21451 & 25.4 & 21038 & 24.9 & 21083 & 24.8 \\
\hline Nitrous Oxide & 42361 & 49.3 & 42303 & 48.9 & 40964 & 48.5 & 40729 & 48.2 & 39504 & 46.5 \\
\hline Spinal & 4179 & 4.9 & 5248 & 6.1 & 6677 & 7.9 & 8672 & 10.3 & 10698 & 12.6 \\
\hline Nil & 11468 & 13.3 & 10518 & 12.2 & 9674 & 11.5 & 9163 & 10.8 & 8896 & 10.5 \\
\hline TOTAL CONFINEMENTS & 85967 & 100.0 & 86460 & 100.0 & 84379 & 100.0 & 84587 & 100.0 & 85032 & 100.0 \\
\hline
\end{tabular}

Source: NSW Midwives Data Collection (HOIST). Centre for Epidemiology and Research, NSW Department of Health.

\# More than one type of pain relief may be used.

\section{Baby sex}

There were no significant changes in the pattern of baby sex since 1999, with slightly more male babies born than females in each year. In 2003, 44,623 (51.6 per cent) of babies were male, 41,722 (48.3 per cent) were female, 19 were of indeterminate sex, and sex was not reported for 50 babies. This compares with babies born in 1999, when 44,805 ( 51.3 per cent) of 87,289 babies were male, 42,473 (48.7 per cent) were female, 10 were of indeterminate sex, and sex was not reported for 1 baby.

\section{Gestational age}

In $2003,7.0$ per cent of babies were born prematurely (less than 37 weeks gestation), similar to the rate of 7.1 per cent in 1999 (Table 15). Over the five-year period, about 90 per cent of babies were born at term (37-41 weeks gestation), and about 2 per cent were postmature (41-plus weeks gestation).

\section{TABLE 15}

BIRTHS BY GESTATIONAL AGE, NSW 1999-2003

\begin{tabular}{|c|c|c|c|c|c|c|c|c|c|c|}
\hline \multirow[t]{2}{*}{$\begin{array}{l}\text { Gestational age } \\
\text { (weeks) }\end{array}$} & \multicolumn{2}{|c|}{1999} & \multicolumn{2}{|c|}{2000} & \multicolumn{2}{|c|}{$\begin{array}{l}\text { Year } \\
2001\end{array}$} & \multicolumn{2}{|c|}{2002} & \multicolumn{2}{|c|}{2003} \\
\hline & No. & $\%$ & No. & $\%$ & No. & $\%$ & No. & $\%$ & No. & $\%$ \\
\hline$<20$ & 0 & 0.0 & 0 & 0.0 & 0 & 0.0 & 1 & 0.0 & 1 & 0.0 \\
\hline $20-27$ & 585 & 0.7 & 623 & 0.7 & 628 & 0.7 & 594 & 0.7 & 585 & 0.7 \\
\hline $28-31$ & 625 & 0.7 & 663 & 0.8 & 667 & 0.8 & 612 & 0.7 & 639 & 0.7 \\
\hline $32-36$ & 5026 & 5.8 & 5114 & 5.8 & 4890 & 5.7 & 4865 & 5.7 & 4810 & 5.6 \\
\hline $37-41$ & 79114 & 90.6 & 79368 & 90.3 & 77566 & 90.3 & 77865 & 90.5 & 78241 & 90.5 \\
\hline $42+$ & 1932 & 2.2 & 2148 & 2.4 & 2093 & 2.4 & 2047 & 2.4 & 2128 & 2.5 \\
\hline Not stated & 7 & 0.0 & 6 & 0.0 & 14 & 0.0 & 21 & 0.0 & 10 & 0.0 \\
\hline TOTAL & 87289 & 100.0 & 87922 & 100.0 & 85858 & 100.0 & 86005 & 100.0 & 86414 & 100.0 \\
\hline
\end{tabular}

Source: NSW Midwives Data Collection (HOIST). Centre for Epidemiology and Research, NSW Department of Health. 


\section{Birthweight}

Since 1999, the rate of low birthweight (less than 2,500 grams) has been about six per cent (Table 16). The rate was 6.2 per cent in 2003.

\section{TABLE 16}

BIRTHS BY BIRTHWEIGHT, NSW 1999-2003

\begin{tabular}{|c|c|c|c|c|c|c|c|c|c|c|}
\hline \multirow[t]{2}{*}{$\begin{array}{l}\text { Birthweight } \\
\text { (grams) }\end{array}$} & \multicolumn{2}{|c|}{1999} & \multicolumn{4}{|c|}{$\begin{array}{l}\text { Year } \\
2001\end{array}$} & \multicolumn{2}{|c|}{2002} & \multicolumn{2}{|c|}{2003} \\
\hline & No. & $\%$ & No. & $\%$ & No. & $\%$ & No. & $\%$ & No. & $\%$ \\
\hline Less than 500 & 212 & 0.2 & 228 & 0.3 & 243 & 0.3 & 212 & 0.2 & 223 & 0.3 \\
\hline 500-999 & 391 & 0.4 & 425 & 0.5 & 416 & 0.5 & 399 & 0.5 & 393 & 0.5 \\
\hline $1000-1499$ & 509 & 0.6 & 546 & 0.6 & 526 & 0.6 & 469 & 0.5 & 497 & 0.6 \\
\hline 1500-1999 & 1076 & 1.2 & 1079 & 1.2 & 1043 & 1.2 & 1083 & 1.3 & 1049 & 1.2 \\
\hline 2000-2499 & 3353 & 3.8 & 3383 & 3.8 & 3283 & 3.8 & 3344 & 3.9 & 3221 & 3.7 \\
\hline 2500-2999 & 12942 & 14.8 & 12819 & 14.6 & 12783 & 14.9 & 12838 & 14.9 & 12877 & 14.9 \\
\hline $3000-3499$ & 30978 & 35.5 & 30647 & 34.9 & 30312 & 35.3 & 30504 & 35.5 & 30803 & 35.6 \\
\hline 3500-3999 & 27173 & 31.1 & 27483 & 31.3 & 26542 & 30.9 & 26676 & 31.0 & 26982 & 31.2 \\
\hline 4000-4499 & 9002 & 10.3 & 9454 & 10.8 & 9060 & 10.6 & 8921 & 10.4 & 8810 & 10.2 \\
\hline $4500+$ & 1629 & 1.9 & 1811 & 2.1 & 1607 & 1.9 & 1509 & 1.8 & 1507 & 1.7 \\
\hline Not stated & 24 & 0.0 & 47 & 0.1 & 43 & 0.1 & 50 & 0.1 & 52 & 0.1 \\
\hline TOTAL & 87289 & 100.0 & 87922 & 100.0 & 85858 & 100.0 & 86005 & 100.0 & 86414 & 100.0 \\
\hline
\end{tabular}

Source: NSW Midwives Data Collection (HOIST). Centre for Epidemiology and Research, NSW Department of Health.

\section{Apgar score}

In 2003, 2.0 per cent of babies were born with an Apgar score of less than seven at five minutes and 1.0 per cent were born with a score less than four (Table 17). These rates are similar to those of previous years.

\section{TABLE 17}

BIRTHS BY APGAR SCORE AT FIVE MINUTES, NSW 1999-2003"

\begin{tabular}{|c|c|c|c|c|c|c|c|c|c|c|}
\hline \multirow[t]{2}{*}{ Apgar score } & \multicolumn{2}{|c|}{1999} & \multicolumn{4}{|c|}{$\begin{array}{l}\text { Year } \\
2001\end{array}$} & \multicolumn{2}{|c|}{2002} & \multicolumn{2}{|c|}{2003} \\
\hline & No. & $\%$ & No. & $\%$ & No. & $\%$ & No. & $\%$ & No. & $\%$ \\
\hline $0-4$ & 996 & 1.1 & 1043 & 1.2 & 922 & 1.1 & 902 & 1.0 & 899 & 1.0 \\
\hline $5-6$ & 1098 & 1.3 & 956 & 1.1 & 938 & 1.1 & 893 & 1.0 & 865 & 1.0 \\
\hline $7+$ & 85028 & 97.4 & 85756 & 97.5 & 83797 & 97.6 & 84033 & 97.7 & 84473 & 97.8 \\
\hline Not stated & 167 & 0.2 & 167 & 0.2 & 201 & 0.2 & 177 & 0.2 & 177 & 0.2 \\
\hline TOTAL & 87289 & 100.0 & 87922 & 100.0 & 85858 & 100.0 & 86005 & 100.0 & 86414 & 100.0 \\
\hline
\end{tabular}

Source: NSW Midwives Data Collection (HOIST). Centre for Epidemiology and Research, NSW Department of Health.

\# Includes stillbirths and live births. 


\section{Special care and neonatal intensive care}

In 2003, 15.0 per cent of babies were admitted to special care units and 2.6 per cent were admitted to neonatal intensive care units (Table 18). These rates are similar to previous years.

\section{TABLE 18}

BIRTHS BY ADMISSION TO SPECIAL CARE OR NEONATAL INTENSIVE CARE UNITS, NSW 1999-2003

\begin{tabular}{|c|c|c|c|c|c|c|c|c|c|c|}
\hline \multirow{3}{*}{ Unit of admission } & \multicolumn{8}{|c|}{ Year } & \multirow{2}{*}{\multicolumn{2}{|c|}{2003}} \\
\hline & \multicolumn{2}{|c|}{1999} & \multicolumn{2}{|c|}{2000} & \multicolumn{2}{|c|}{2001} & \multicolumn{2}{|c|}{2002} & & \\
\hline & No. & $\%$ & No. & $\%$ & No. & $\%$ & No. & $\%$ & No. & $\%$ \\
\hline Special care unit & 14430 & 16.5 & 13842 & 15.7 & 12900 & 15.0 & 12740 & 14.8 & 12926 & 15.0 \\
\hline Neonatal intensive care unit & 2306 & 2.6 & 2147 & 2.4 & 2190 & 2.6 & 2196 & 2.6 & 2277 & 2.6 \\
\hline TOTAL & 87289 & 100.0 & 87922 & 100.0 & 85858 & 100.0 & 86005 & 100.0 & 86414 & 100.0 \\
\hline
\end{tabular}

Source: NSW Midwives Data Collection (HOIST). Centre for Epidemiology and Research, NSW Department of Health.

\section{Perinatal outcome}

In the period 1999-2003 the perinatal mortality rate varied from 8.6 to 9.6 per 1,000 (Table 19). In 2003, 70.3 per cent of all reported perinatal deaths were stillbirths and 29.7 per cent were neonatal deaths.

In 2003, of the 744 perinatal deaths in NSW, 718 (96.5 per cent) were reported among planned hospital births, 13 (1.7 per cent) among planned birth centre births, 2 occurred among planned home births, and 11 were among babies born before arrival at hospital.

\section{TABLE 19}

BIRTHS BY PERINATAL OUTCOME, NSW 1999-2003"

\begin{tabular}{|c|c|c|c|c|c|c|c|c|c|c|c|}
\hline \multirow[t]{2}{*}{ Year } & \multirow{2}{*}{$\begin{array}{l}\text { Liveborn } \\
\text { surviving } \\
\text { No. }\end{array}$} & \multirow[b]{2}{*}{$\%$} & \multicolumn{2}{|c|}{ Stillborn } & \multicolumn{2}{|c|}{$\begin{array}{c}\text { Perinatal Outcome } \\
\text { Neonatal } \\
\text { death }\end{array}$} & \multicolumn{2}{|c|}{ Not stated } & \multicolumn{2}{|c|}{$\begin{array}{l}\text { Total } \\
\text { births }\end{array}$} & \multirow[t]{2}{*}{$\begin{array}{l}\text { Perinatal mortality } \\
\text { rate } / 1,000 \text { births }\end{array}$} \\
\hline & & & No. & $\%$ & No. & $\%$ & No. & $\%$ & No. & $\%$ & \\
\hline 1999 & 86473 & 99.1 & 533 & 0.6 & 266 & 0.3 & 17 & 0.0 & 87289 & 100.0 & 9.2 \\
\hline 2000 & 87076 & 99.0 & 595 & 0.7 & 247 & 0.3 & 4 & 0.0 & 87922 & 100.0 & 9.6 \\
\hline 2001 & 85063 & 99.1 & 538 & 0.6 & 251 & 0.3 & 6 & 0.0 & 85858 & 100.0 & 9.2 \\
\hline 2002 & 85222 & 99.1 & 515 & 0.6 & 233 & 0.3 & 35 & 0.0 & 86005 & 100.0 & 8.7 \\
\hline 2003 & 85669 & 99.1 & 523 & 0.6 & 221 & 0.3 & 1 & 0.0 & 86414 & 100.0 & 8.6 \\
\hline
\end{tabular}

Source: NSW Midwives Data Collection (HOIST). Centre for Epidemiology and Research, NSW Department of Health.

\# Perinatal deaths include deaths reported to the MDC only. As the MDC form is completed at discharge or transfer of the baby, deaths occurring after this time may not be reported to the MDC. 


\section{Maternal deaths}

In the period 1990-2001, 137 deaths were reported among pregnant women or women who gave birth less than six weeks previously. Of these, 44 (32.1 per cent) died of incidental causes not related to the pregnancy or its management; 63 (46.0 per cent) deaths were found to be directly due to pregnancy or its management; 29 (21.2 per cent) deaths were found to result from pre-existing disease or disease which developed during pregnancy (not due to direct obstetric causes), but which may have been aggravated by the physiologic effects of pregnancy; and there was one death for which the cause was not determined (Table 20). Table 21 shows maternal deaths by cause in NSW for 2001 .

\section{TABLE 20}

\section{MATERNAL DEATHS BY YEAR, NSW 1990-2002"}

\begin{tabular}{|c|c|c|c|c|c|c|c|c|c|c|}
\hline \multirow[t]{2}{*}{ Year } & \multicolumn{2}{|c|}{ Direct } & \multicolumn{2}{|c|}{ Indirect } & \multicolumn{2}{|c|}{$\begin{array}{c}\text { Classification } \\
\text { Total } \\
\text { Direct \& Indirect }\end{array}$} & \multicolumn{2}{|c|}{ Incidental } & \multicolumn{2}{|c|}{ TOTAL } \\
\hline & No. & $\begin{array}{r}\text { Ratio/ } \\
100,000\end{array}$ & No. & $\begin{array}{r}\text { Ratio/ } \\
100,000\end{array}$ & No. & $\begin{array}{r}\text { Ratio/ } \\
100,000\end{array}$ & No. & $\begin{array}{r}\text { Ratio/ } \\
100,000\end{array}$ & No. & $\begin{array}{r}\text { Ratio/ } \\
100,000\end{array}$ \\
\hline 1990 & 4 & 4.6 & 6 & 6.9 & 10 & 11.6 & 2 & 2.3 & 12 & 13.9 \\
\hline 1991 & 4 & 4.7 & 1 & 1.2 & 5 & 5.8 & 1 & 1.2 & 6 & 7.0 \\
\hline 1992 & 5 & 5.7 & 1 & 1.1 & 6 & 6.8 & 5 & 5.7 & 11 & 12.5 \\
\hline 1993 & 6 & 6.9 & 1 & 1.2 & 7 & 8.1 & 6 & 6.9 & 13 & 15.0 \\
\hline 1994 & 8 & 9.2 & 1 & 1.2 & 9 & 10.4 & 3 & 3.5 & 12 & 13.8 \\
\hline 1995 & 7 & 8.1 & 2 & 2.3 & 9 & 10.4 & 6 & 7.0 & 15 & 17.4 \\
\hline 1996 & 6 & 7.0 & 1 & 1.2 & 7 & 8.2 & 5 & 5.9 & 12 & 14.1 \\
\hline 1997 & 7 & 8.1 & 2 & 2.3 & 9 & 10.5 & 5 & 5.8 & 14 & 16.1 \\
\hline 1998 & 4 & 4.7 & 4 & 4.7 & 8 & 9.4 & 3 & 3.5 & 11 & 12.9 \\
\hline $1999^{\# \#}$ & 4 & 4.7 & 1 & 1.2 & 5 & 5.8 & 6 & 7.0 & 12 & 14.0 \\
\hline 2000 & 4 & 4.7 & 5 & 5.9 & 9 & 10.7 & 1 & 1.2 & 10 & 11.9 \\
\hline 2001 & 4 & 4.7 & 4 & 4.7 & 8 & 9.5 & 1 & 1.2 & 9 & 10.7 \\
\hline $2002^{\# \# \#}$ & & & & & & & & & 6 & 7.1 \\
\hline
\end{tabular}

\section{Source: NSW Maternal and Perinatal Committee.}

\# Includes all deaths of women who were pregnant at the time of death, or who died within 42 days of childbirth. Direct deaths include those resulting from obstetric complications of the pregnant state, including its management. Indirect deaths include those resulting from preexisting disease or disease which developed during pregnancy and was not due to direct obstetric causes but which may have been aggravated by the physiological effects of pregnancy. Incidental deaths are those where the pregnancy is unlikely to have contributed significantly to the death. ${ }^{1}$

\#\# Total for 1999 includes one death of undetermined cause

\#\#\# Classification incomplete for 2002.

\section{TABLE 21}

MATERNAL DEATHS BY CAUSE, NSW $2001^{\#}$

\begin{tabular}{|c|c|c|}
\hline Classification & Cause & No. \\
\hline Direct & Pulmonary embolus following deep vein thrombosis & 1 \\
\hline Direct & Suppurative basal meningitis & 1 \\
\hline Direct & Strep. Pyogenes septicemia & 1 \\
\hline Direct & Amniotic fluid embolism & 1 \\
\hline Indirect & Intracerebral haemorrhage & 1 \\
\hline Indirect & Myocarditis & 1 \\
\hline Indirect & Aortic dissection & 1 \\
\hline Indirect & Intra-cerebral haemorrhage due to rupture of vascular malformation & 1 \\
\hline Incidental & Multiple injuries following motor vehicle accident & 1 \\
\hline TOTAL & & 9 \\
\hline
\end{tabular}

Source: NSW Maternal and Perinatal Committee.

\# Includes all deaths of women who were pregnant at the time of death, or who died within 42 days of childbirth. Direct deaths include those resulting from obstetric complications of the pregnant state, including its management. Indirect deaths include those resulting from preexisting disease or disease which developed during pregnancy and was not due to direct obstetric causes but which may have been aggravated by the physiological effects of pregnancy. Incidental deaths are those where the pregnancy is unlikely to have contributed significantly to the death.

\section{Reference}

1. Slaytor EK, Sullivan EA, King JF. Maternal deaths in Australia 1997-1999. AIHW Catalogue no. PER 24. Sydney: AIHW National Perinatal Statistics Unit, 2004. 